\title{
Live and internal organ weights of male growing pigs fed low protein and low energy
} diets supplemented with multi-enzyme

${ }^{1}$ Amaefule, R. A., ${ }^{1}$ Onunkwo, D. N., ${ }^{2}$ Ilouno O. C., ${ }^{2}$ Iwuji, T. C., ${ }^{2}$ Ogbuewu, I. P., and

${ }^{2}$ Etuk, I. F

${ }^{1}$ College of Animal Science and Animal Production, Michael Okpara University of Agriculture, Umudike, Abia State, Nigeria,

${ }^{2}$ Department of Animal Science and Technology,

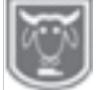

Federal University of Technology, P.M.B 1526, Owerri, Imo State, Nigeria

Abstract

Corresponding author: donunkwo1@gmail.com; +2348033388622

Organ characteristics of male growing male pigs fed low crude protein and low energy diets supplemented with multi-enzyme were determined using 36 hybrid (Landrace $x$ Large white) male pigs of 8-10 weeks old. Two metabolizable energy (3000 and $2600 \mathrm{Kcal} \mathrm{ME} / \mathrm{kg}$ ) and three crude protein levels $(14,16$ and $18 \% \mathrm{CP})$ were used to formulate six dietary treatments; T1: control (3000 Kcal ME/kg; $18 \% \mathrm{CP}), T 2$ (3000 Kcal ME/Kg; $16 \% \mathrm{CP}), \mathrm{T3}$ (3000 Kcal ME/kg; $14 \%$ CP), T4 (2600 Kcal ME/kg; $18 \%$ CP), $T 5$ (2600 Kcal ME/kg; $16 \%$ $\mathrm{CP})$ and $\mathrm{T6}(2600 \mathrm{Kcal} \mathrm{ME} / \mathrm{kg} ; 14 \% \mathrm{CP})$. The enzyme was added to all the treatments at $1 \mathrm{~g} / \mathrm{kg}$ diet except the control. The treatments were replicated three times with two pigs per replicate. The experiment was a $2 \times 3$ factorial. The pigs were starved for 12 hours but allowed access to drinking water, stunned and bled completely. It was cut open though the thorax region along the underline to the abdomen, exposing the entire internal organs and GIT contents. The heart, lungs, liver, kidneys, spleen and other internal organs were examined, carefully removed and weighed with a sensitive electronic kitchen scale, model SF-400. Higher $(P<0.05)$ live weight $(33500.00 \mathrm{~g})$, with lower $(P<0.05)$ mean values for heart and viscera were recorded in male growing pigs fed T4. Male growing pigs fed with T3 and T6 had lower $(P<0.05)$ live weight $(12200.00 \mathrm{~g}$ and $11500.00 \mathrm{~g})$, and higher $(P<0.05)$ relative internal organs. Male growing pigs fed $14 \%$ CP diets (T3 and T6) with their corresponding metabolizable energy levels (3000kcal and 2600kcal) recorded higher $(P<0.05)$ heart and viscera's values. Keeping growing (male) pigs on low crude protein diets (14\%) supplemented with multi-enzyme, irrespective of the energy levels, did not improve live weight but increased relative organ weight.

Keywords: Crude protein, Grower pigs, Organ characteristics, Metabolizable energy, Multi-enzyme

\section{Les Poids des organes vivants et internes des porcs mâles en croissance nourris avec des régimes pauvres en protéines et en énergie complétés par des multi-enzymes}

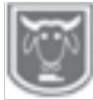

\section{Résumé}

Les caractéristiques des organes de porcs mâles en croissance nourris à faible en protéines brutes et en énergie mais plutôt supplémentée en multi-enzymes ont été déterminées en utilisant 36 porcs mâles hybrides (Landrace $x$ Large white) âgés de 8 à 10 semaines. Deux énergies métabolisables (3000 et $2600 \mathrm{Kcal} \mathrm{ME/kg)} \mathrm{et} \mathrm{trois} \mathrm{niveaux} \mathrm{de} \mathrm{protéines} \mathrm{brutes} \mathrm{(14,}$ 16 et $18 \% \mathrm{CP}$ ) ont été utilisés pour formuler six traitements diététiques ; T1 : contrôle (3000 $\mathrm{Kcal} \mathrm{ME} / \mathrm{kg} ; 18 \% \mathrm{CP}), \mathrm{T} 2(3000 \mathrm{Kcal} \mathrm{ME} / \mathrm{Kg} ; 16 \% \mathrm{CP}), \mathrm{T} 3(3000 \mathrm{Kcal} \mathrm{ME} / \mathrm{kg} ; 14 \%$ CP), T4 (2600 Kcal ME / kg ; $18 \% \mathrm{CP}), T 5(2600 \mathrm{Kcal} \mathrm{ME} / \mathrm{kg} ; 16 \% \mathrm{CP})$ et T6 $(2600 \mathrm{Kcal}$ 
$\mathrm{ME} / \mathrm{kg} ; 14 \% \mathrm{CP})$. L'enzyme a été ajoutée à tous les traitements à raison de $1 \mathrm{~g} / \mathrm{kg}$ de régime sauf le témoin. Les traitements ont été répliqués trois fois avec deux porcs par réplica. L'expérience était une factorielle $2 \times 3$. Les porcs ont été affamés pendant 12 heures mais ont eu accès à l'eau potable, étourdis et saignaient complètement. Il a été ouvert à travers la région du thorax le long du trait de soulignement jusqu'à l'abdomen, exposant l'ensemble des organes internes et le contenu du 'GIT'. Le cœur, les poumons, le foie, les reins, la rate et d'autres organes internes ont été examinés, soigneusement prélevés et pesés avec une balance de cuisine électronique sensible, modèle $S F-400$. Un poids vif plus élevé $(P<0,05)$ $(33500,00 \mathrm{~g})$, avec des valeurs moyennes plus faibles $(P<0,05)$ pour le cœur et les viscères ont été enregistrés chez des porcs en croissance mâles nourris au T4. Les porcs mâles en croissance nourris avec T3 et T6 avaient des organes internes relatifs inférieurs $(P<0,05)$ (12 200,00 g et 11500,00 g) et supérieurs $(P<0,05)$. Les porcs mâles en croissance nourris avec $14 \%$ de régimes 'CP' (T3 et T6) avec leurs niveaux d'énergie métabolisables correspondants $(3000 \mathrm{kcal}$ et $2600 \mathrm{kcal})$ ont enregistré des valeurs cardiaques et viscérales plus élevées $(P<0,05)$. Le fait de garder les porcs en croissance (mâles) avec des régimes pauvres en protéines brutes (14\%) supplémentés en multi-enzymes, quels que soient les niveaux d'énergie, n'a pas amélioré le poids vif mais augmenté le poids relatif des organes.

Mots clés : protéine brute, porc de croissance, caractéristiques des organes, énergie métabolisable, multi-enzyme

\section{Introduction}

Swine production has a high potential to mitigate shortage of animal protein in Nigeria and contribute to economic development as pigs have high fecundity, high feed conversion ratio, early maturity, short generation interval and relatively small space requirement (Lekule and Kyvsgaard, 2003). Pigs provide about 44\% of meat in the world market (FAO, 2001) as pig production represents one of the fastest means of correcting animal protein shortage in Africa. Apart from their high rate of reproduction, pigs are efficient nutrient converters into high quality protein in the form of meat (Tewe and Egbunike, 1988). A major constraint in the use of feed stuffs like Agro Industrial By-products (AIBPs) such as breweries dried grain, rice milling waste, etc, is their high crude fibre levels. Pigs are of socio-economic value to smallholder farmers and provide a safety net in times of financial crisis (Githigia, et al., 2012). A short breeding cycle, high fecundity, high feed conversion efficiency and increasing demand are major drivers of growth in this sub-sector. In communities currently experiencing a shift from ruminant to non-ruminant livestock production, pig farming is becoming relevant (Githigia, et al., 2012., Serem et al., 2017). However, expansion and profitability are constrained by increasing feed costs, these have led to the use of agroindustrial by-products such as maize offal, palm kernel meal and brewers dried gains in monogastric animal feeding. The use these agro-industrial by-products has been limited by high level of crude fibre and nonstarch polysaccharides (NSPs) contained in their cell wall, which may not be digested by the endogenous enzymes of monogastric animals (Dalolio et al., 2016). In order to improve the utilization of such feed stuffs, nutritionists have proposed the use of exogenous enzymes to help break down fibre and NSPs, thereby enhancing nutrient release from these by-products (Amaefule et al., 2009), especially energy and protein content of the feed ingredients. Protein and energy are two important components of feed that are major determinants of the performance and productivity of farm animals (Dairo et al., 2010; Amaefule et al., 2019). Protein sources for animal feeding are generally more expensive than energy 
sources such that their reduced inclusion level in diets could save the cost of feeds and that of animal production (Ajayi 2014; Amaefule et al., 2019). For pig production, the regime of dietary protein and energy has been established both in the tropics and temperate climates. Low energy and low protein diets have been tried in an attempt at resolving such problems of high nutrient density diet, and it has been revealed that overall performance is not totally affected in pigs and broilers (Amaefule and Onyejekwe, 2015; Amaefule, 2016; Amaefule et al., 2019). Recently, several research studies have been conducted with enzymes and have been reported to cause reduction of nutrient levels in diets in order to maximize profit, reduce amount lost in faecal matter and to maintain environmentally friendly (odour control) pig farm (Ajayi and Imouokhome, 2015). Organ characteristics of sows fed enzyme supplemented diet have been investigated by Unigwe et al. (2017) who reported that sows fed 3118.39 kcal ME with a corresponding crude protein of $20.47 \%$ diet, supplemented with multi-enzyme (1g/10kg diet) favored weights of visceral organs.

In a study conducted with broiler birds by Amaefule, 2016 and Amaefule et al. 2019, reported that supplementing low energy and low protein diets with multi-enzyme $(1 \mathrm{~g} / \mathrm{kg}$ diet $)$ increased the relative weight of liver and lungs of starter broiler birds, such data on male grower pigs is scanty, making this study worthy of investigation. Therefore, this work was aimed at investigating organ characteristics of male grower pigs fed low protein and low energy diets supplemented with multi-enzyme (enziblend plus + ) in a humid tropical environment.

\section{Materials and methods \\ Experimental site}

This research was conducted at the Piggery Unit, Teaching and Research Farm, School of Agriculture and Agricultural Technology, Federal University of Technology Owerri, Imo State; Nigeria.

\section{Experimental diet}

Two metabolizable energy (3000 and 2600 $\mathrm{Kcal} \mathrm{ME} / \mathrm{kg}$ ) and three crude protein (14, 16 and $18 \% \mathrm{CP}$ ) levels were used to formulate six dietary treatments; $\mathrm{T} 1$ : control (3000 Kcal ME/Kg; $18 \% \mathrm{CP}$ ). The experiment was a $2 \times 3$ factorial in a Completely Randomized Design (CRD) with model;

$\mathrm{Y}_{\mathrm{ijk}}=\mu+\mathrm{E}_{\mathrm{i}}+\mathrm{P}_{\mathrm{j}}+(\mathrm{EP})_{\mathrm{ij}}+\mathrm{e}_{\mathrm{ijk}}$

Where;

$\mathrm{Y}_{\mathrm{ij} \mathrm{k}}$; Single observation

$\mu$ : Overall mean

$\mathrm{E}_{\mathrm{i}}$ : Energy effect

$\mathrm{P}_{\mathrm{j}}$ : Protein effect

$(\mathrm{EP})_{\mathrm{ij}}$ : Energy $\mathrm{x}$ Protein interaction effect $\mathrm{e}_{\mathrm{ijk}}:$ Error term

Table 1: Percentage composition of the experimental diet

\begin{tabular}{lllllll}
\hline Feeds Ingredients & $\mathrm{T} 1$ & $\mathrm{~T} 2$ & $\mathrm{~T} 3$ & $\mathrm{~T} 4$ & $\mathrm{~T} 5$ & $\mathrm{~T} 6$ \\
\hline Maize Offal & 42.70 & 48.95 & 55.20 & 42.70 & 48.95 & 55.20 \\
Soybean Meal & 13.50 & 7.25 & 1.00 & 13.50 & 7.25 & 1.00 \\
PKC & 40.00 & 40.00 & 40.00 & 40.00 & 40.00 & 40.00 \\
Bone & 3.00 & 3.00 & 3.00 & 3.00 & 3.00 & 3.00 \\
Vitamin premix* & 0.25 & 0.25 & 0.25 & 0.25 & 0.25 & 0.25 \\
NaCl & 0.25 & 0.25 & 0.25 & 0.25 & 0.25 & 0.25 \\
Lysine & 0.20 & 0.20 & 0.20 & 0.20 & 0.20 & 0.20 \\
Methionine & 0.10 & 0.10 & 0.10 & 0.10 & 0.10 & 0.10 \\
Total & 100.00 & 100.00 & 100.00 & 100.00 & 100.00 & 100.00 \\
CP (\%) & 18.00 & 16.00 & 14.00 & 18.00 & 16.00 & 14.00 \\
Crude fibre (\%) & 12.01 & 12034 & 12.69 & 12.01 & 12034 & 12.69 \\
Palm oil supp. & 4.65 & 4.40 & 4.20 & - & & - \\
ME (Kcal/kg) & 3000.00 & 3000.00 & 3000.00 & 2600.00 & 2600.00 & 2600 \\
\hline
\end{tabular}


Experimental pigs and management

A total of 36 hybrid (Landrace $\mathrm{x}$ Large white) male pigs of 8-10 weeks old, with an average weight of $8.0 \mathrm{~kg}$ were used to conduct this study. The pigs were housed in a tropical-type, open-sided pig house roofed with asbestos roofing sheets. The open sides of the house were covered with iron nets to screen out flies and other insects. The pigs were provided with experimental diets and water ad libitum for 99 days.

\section{Data collection}

The pigs were starved for 12 hours but allowed access to drinking water, stunned and bled completely. It was cut open though the thorax region along the underline to the abdomen, exposing the entire internal organs and GIT contents. The heart, lungs, liver, kidneys, spleen and other internal organs were examined, carefully removed and weighed with a sensitive electronic kitchen scale, model SF-400. Stomach, small intestine, large intestine and caecum were also examined, carefully removed and weighed both full and empty. Data collected were subjected to analysis of variance (ANOVA) for a $2 \times 3$ factorial experiment in a Completely Randomized Design (Steel and Torrie, 1997). Statistical computations were done using Statistical Package for Social Sciences (SPSS, 2002), while difference between treatments means were separated using Duncan's Multiple Range Test. Energy effect was subjected to simple T-test analysis of the same statistical package.

Table 2: Composition of the multi-enzyme

\begin{tabular}{ll}
\hline Ingredients & Units \\
\hline Serine Protease & $7500.00 \mathrm{PRT} / \mathrm{g}$ \\
Endo-1,4-beta glucanase & $64.00 \mathrm{U} / \mathrm{g}$ \\
Endo-1,3(4)-beta glucanase & $56.00 \mathrm{U} / \mathrm{g}$ \\
Endo-1,4-beta-xylanase & $216.00 \mathrm{U} / \mathrm{g}$ \\
Alfa-amylase & $4.00 \mathrm{KNU} / \mathrm{g}$ \\
Anti-caking (Sepiolite, E562) & $350,000 \mathrm{mg} / \mathrm{kg}$ \\
Calcium & $17.90 \%$ \\
Sodium & $2.07 \%$ \\
Magnesium & $4.03 \%$ \\
\hline
\end{tabular}

Usage; $1.00 \mathrm{~kg} /$ ton of feed

\section{Results and discussion}

Effect of low energy diets supplemented with multi-enzyme on live and relative organs weight of male growing pigs is shown in Table 2. Live weight $(23033.33 \pm 4031.50 \mathrm{~g})$ and lungs $(0.88 \pm 0.06 \%)$ of male growing pigs fed 2600 kcal metabolizable energy (ME) diet were higher than those fed $3000 \mathrm{kcal} \mathrm{ME}$ diet for growing pigs when compared. While testis of male growing pigs fed diets with $3000 \mathrm{kcal}$ metabolizable energy level had higher mean value $(0.64 \pm 0.02 \%)$ than those fed low energy $(2600 \mathrm{kcal} / \mathrm{kg})$ diets supplemented with multi-enzyme when compared using T-test. 
Table 2: Effect of low energy diets supplemented with multi-enzyme on live and relative organs weight of male growing pigs

\begin{tabular}{lll}
\hline Parameters $(\%)$ & $3000 \mathrm{Kcal} / \mathrm{kg}$ & $2600 \mathrm{Kcal} / \mathrm{kg}$ \\
\hline Live weight $(\mathrm{g})$ & $20700.00 \pm 3647.46$ & $23033.33 \pm 4031.50$ \\
Heart & $0.42 \pm 0.03$ & $0.43 \pm 0.04$ \\
Lungs & $0.77 \pm 0.02$ & $0.88 \pm 0.06$ \\
Liver & $2.07 \pm 0.08$ & $1.91 \pm 0.04$ \\
Kidney & $0.33 \pm 0.02$ & $0.30 \pm 0.01$ \\
Spleen & $0.13 \pm 0.00$ & $0.13 \pm 0.00$ \\
Testis & $0.64 \pm 0.02$ & $0.49 \pm 0.09$ \\
Full Caecum & $0.90 \pm 0.02$ & $0.97 \pm 0.04$ \\
Empty Caecum & $0.27 \pm 0.02$ & $0.26 \pm 0.03$ \\
Full small intestine & $3.72 \pm 0.21$ & $3.36 \pm 0.14$ \\
Empty small intestine & $2.05 \pm 0.01$ & $1.45 \pm 0.25$ \\
Full large intestine & $6.71 \pm 0.12$ & $5.67 \pm 0.40$ \\
Empty large intestine & $1.76 \pm 0.03$ & $1.39 \pm 0.14$ \\
Full stomach & $1.71 \pm 0.06$ & $1.58 \pm 0.16$ \\
Empty stomach & $1.03 \pm 0.05$ & $1.06 \pm 0.07$ \\
\hline
\end{tabular}

Mean \pm SE: Standard error

Table 3 presents the effect of low crude protein (CP) diets supplemented with multi-enzyme on live relative organs weight of male growing pigs. Male growing pigs fed $14 \%$ crude protein diet supplemented with multi-enzyme recorded significantly $(\mathrm{P}<0.05)$ higher mean value for all the parameters measured except for live weight of pigs fed $14 \% \mathrm{CP}$ diet with the least $(\mathrm{P}<0.05)$ mean value $(11850.00 \mathrm{~g})$. Lungs, kidney and full stomach of male growing pigs fed $16 \% \mathrm{CP}$ supplemented with multi-enzyme were similar with those of pigs fed $14 \%$ CP diet supplemented with multi-enzyme.

Table 3: Effect of low protein diets supplemented with multi-enzyme on live and relative organs weight of male growing pigs

\begin{tabular}{lllll}
\hline Parameters $(\%)$ & $18 \%$ & $16 \%$ & $14 \%$ & SEM \\
\hline Live weight $(\mathrm{g})$ & $32600.00^{\mathrm{a}}$ & $21150.00^{\mathrm{b}}$ & $11850.00^{\mathrm{c}}$ & 2615.57 \\
Heart & $0.32^{\mathrm{c}}$ & $0.43^{\mathrm{b}}$ & $0.52^{\mathrm{a}}$ & 0.27 \\
Lungs & $0.75^{\mathrm{b}}$ & $0.79^{\mathrm{ab}}$ & $0.94^{\mathrm{a}}$ & 0.03 \\
Liver & 1.95 & 1.97 & 2.05 & 0.05 \\
Kidney & $0.28^{\mathrm{b}}$ & $0.31^{\mathrm{ab}}$ & $0.35^{\mathrm{a}}$ & 0.01 \\
Spleen & 0.11 & 0.12 & 0.14 & 0.00 \\
Testis & 0.56 & 0.55 & 0.58 & 0.05 \\
Full Caecum & 0.86 & 0.98 & 0.97 & 0.02 \\
Empty Caecum & $0.22^{\mathrm{b}}$ & $0.22^{\mathrm{b}}$ & $0.35^{\mathrm{a}}$ & 0.01 \\
Full small intestine & $3.02^{\mathrm{b}}$ & $3.73^{\mathrm{a}}$ & $3.86^{\mathrm{a}}$ & 0.13 \\
Empty small intestine & $1.22^{\mathrm{b}}$ & $2.00^{\mathrm{b}}$ & $2.03^{\mathrm{a}}$ & 0.15 \\
Full large intestine & 6.15 & 6.72 & 5.70 & 0.25 \\
Empty large intestine & 1.41 & 1.82 & 1.49 & 0.08 \\
Full stomach & $1.39^{\mathrm{b}}$ & $1.65^{\mathrm{ab}}$ & $1.89^{\mathrm{a}}$ & 0.08 \\
Empty stomach & $0.87^{\mathrm{b}}$ & $1.20^{\mathrm{a}}$ & $1.06^{\mathrm{a}}$ & 0.04 \\
\hline a,b,c Mean values within rows with different superscript letters are significantly different (P<0.05), SEM: Standard \\
error of mean
\end{tabular}




\section{Live and internal organ weights of male growing pigs fed low protein and low energy diets}

Table 4: Interaction effect of low energy and low protein diets supplemented with multi-enzyme on the live and relative organs weight of male grower pigs.

\begin{tabular}{|c|c|c|c|c|c|c|}
\hline Parameters (\%) & $\begin{array}{l}\text { Energy/protein } \\
\text { levels }\end{array}$ & $18 \%$ & $16 \%$ & $14 \%$ & Mean & $\begin{array}{l}\text { SEM (E } \\
x P)\end{array}$ \\
\hline \multirow[t]{3}{*}{ Live weight (g) } & $3000 \mathrm{Kcal} / \mathrm{kg}$ & $31700.00^{\mathrm{b}}$ & $18200.00^{\mathrm{d}}$ & $12200.00^{\mathrm{e}}$ & 20700.00 & \\
\hline & $2600 \mathrm{Kcal} / \mathrm{kg}$ & $33500.00^{\mathrm{a}}$ & $24100.00^{c}$ & $11500.00^{\mathrm{f}}$ & 23033.00 & 2615.57 \\
\hline & Mean & 32600.00 & 21150.00 & 11850.00 & & \\
\hline \multirow[t]{3}{*}{ Heart } & $3000 \mathrm{Kcal} / \mathrm{kg}$ & $0.31^{\mathrm{e}}$ & $0.47^{\mathrm{b}}$ & $0.49^{\mathrm{b}}$ & 0.42 & \\
\hline & $2600 \mathrm{Kcal} / \mathrm{kg}$ & $0.34^{\mathrm{de}}$ & $0.39^{\mathrm{c}}$ & $0.56^{\mathrm{a}}$ & 0.43 & 0.02 \\
\hline & Mean & 0.32 & 0.43 & 0.52 & & \\
\hline \multirow[t]{3}{*}{ Lungs } & $3000 \mathrm{Kcal} / \mathrm{kg}$ & $0.78^{\mathrm{b}}$ & $0.73^{\mathrm{b}}$ & $0.81^{\mathrm{b}}$ & 0.77 & \\
\hline & $2600 \mathrm{Kcal} / \mathrm{kg}$ & $0.73^{\mathrm{b}}$ & $0.85^{\mathrm{b}}$ & $1.08^{\mathrm{a}}$ & 0.88 & 0.03 \\
\hline & Mean & 0.75 & 0.79 & 0.94 & & \\
\hline \multirow[t]{3}{*}{ Liver } & $3000 \mathrm{Kcal} / \mathrm{kg}$ & $1.89^{\mathrm{b}}$ & $2.02^{\mathrm{b}}$ & $2.31^{\mathrm{a}}$ & 2.07 & \\
\hline & $2600 \mathrm{Kcal} / \mathrm{kg}$ & $1.93^{\mathrm{b}}$ & $1.80^{\mathrm{b}}$ & $1.99^{\mathrm{b}}$ & 1.90 & 0.05 \\
\hline & Mean & 1.91 & 1.91 & 2.15 & & \\
\hline \multirow[t]{3}{*}{ Kidney } & $3000 \mathrm{Kcal} / \mathrm{kg}$ & $0.27^{\mathrm{c}}$ & $0.34^{\mathrm{ab}}$ & $0.37^{\mathrm{a}}$ & 0.32 & \\
\hline & $2600 \mathrm{Kcal} / \mathrm{kg}$ & $0.30^{\mathrm{bc}}$ & $0.28^{\mathrm{bc}}$ & $0.33^{\mathrm{abc}}$ & 0.30 & 0.01 \\
\hline & Mean & 0.28 & 0.31 & 0.35 & & \\
\hline \multirow[t]{3}{*}{ Spleen } & $3000 \mathrm{Kcal} / \mathrm{kg}$ & 0.12 & 0.12 & 0.14 & 0.12 & \\
\hline & $2600 \mathrm{Kcal} / \mathrm{kg}$ & 0.11 & 0.12 & 0.15 & 0.12 & 0.01 \\
\hline & Mean & 0.11 & 0.12 & 0.14 & & \\
\hline \multirow[t]{3}{*}{ Testis } & $3000 \mathrm{Kcal} / \mathrm{kg}$ & 0.62 & 0.71 & 0.60 & 0.64 & \\
\hline & $2600 \mathrm{Kcal} / \mathrm{kg}$ & 0.50 & 0.40 & 0.56 & 0.48 & 0.05 \\
\hline & Mean & 056 & 0.55 & 0.58 & & \\
\hline \multirow[t]{3}{*}{ Full Caecum } & $3000 \mathrm{Kcal} / \mathrm{kg}$ & 0.83 & 0.96 & 0.91 & 0.90 & \\
\hline & $2600 \mathrm{Kcal} / \mathrm{kg}$ & 0.89 & 1.00 & 1.04 & 0.97 & 0.06 \\
\hline & Mean & 0.86 & 0.98 & 0.97 & & \\
\hline \multirow[t]{3}{*}{ Empty Caecum } & $3000 \mathrm{Kcal} / \mathrm{kg}$ & $0.24^{\mathrm{b}}$ & $0.23^{\mathrm{b}}$ & $0.35^{\mathrm{a}}$ & 0.27 & \\
\hline & $2600 \mathrm{Kcal} / \mathrm{kg}$ & $0.21^{\mathrm{b}}$ & $0.22^{\mathrm{b}}$ & $0.35^{\mathrm{a}}$ & 0.26 & 0.01 \\
\hline & Mean & 0.22 & 0.22 & 0.35 & & \\
\hline \multirow[t]{3}{*}{ Full small intestine } & $3000 \mathrm{Kcal} / \mathrm{kg}$ & $3.05^{\mathrm{d}}$ & $4.16^{\mathrm{a}}$ & $3.95^{\mathrm{b}}$ & 3.72 & \\
\hline & $2600 \mathrm{Kcal} / \mathrm{kg}$ & $2.99^{d}$ & $3.31^{\mathrm{c}}$ & $3.78^{\mathrm{b}}$ & 3.36 & 0.13 \\
\hline & Mean & 3.02 & 3.73 & 3.86 & & \\
\hline \multirow[t]{3}{*}{ Empty small intestine } & $3000 \mathrm{Kcal} / \mathrm{kg}$ & $1.77^{\mathrm{c}}$ & $2.31^{\mathrm{a}}$ & $2.07^{\mathrm{b}}$ & 2.05 & \\
\hline & $2600 \mathrm{Kcal} / \mathrm{kg}$ & $0.68^{d}$ & $1.70^{\mathrm{c}}$ & $1.99^{\mathrm{b}}$ & 1.45 & 0.15 \\
\hline & Mean & 1.22 & 2.00 & 2.03 & & \\
\hline \multirow[t]{3}{*}{ Full large intestine } & $3000 \mathrm{Kcal} / \mathrm{kg}$ & $6.32^{\mathrm{c}}$ & $6.87^{\mathrm{a}}$ & $6.94^{\mathrm{a}}$ & 6.71 & \\
\hline & $2600 \mathrm{Kcal} / \mathrm{kg}$ & $5.99^{d}$ & $6.58^{\mathrm{b}}$ & $4.46^{\mathrm{e}}$ & 5.67 & 0.25 \\
\hline & Mean & 6.15 & 6.72 & 5.70 & & \\
\hline \multirow[t]{3}{*}{ Empty large intestine } & $3000 \mathrm{Kcal} / \mathrm{kg}$ & $1.66^{\mathrm{b}}$ & $1.80^{\mathrm{a}}$ & $1.82^{\mathrm{a}}$ & 1.76 & \\
\hline & $2600 \mathrm{Kcal} / \mathrm{kg}$ & $1.16^{\mathrm{c}}$ & $1.84^{\mathrm{a}}$ & $1.17^{\mathrm{c}}$ & 1.39 & 0.08 \\
\hline & Mean & 1.41 & 1.82 & 1.49 & & \\
\hline \multirow[t]{3}{*}{ Full stomach } & $3000 \mathrm{Kcal} / \mathrm{kg}$ & $1.54^{\mathrm{d}}$ & $1.91^{\mathrm{b}}$ & $1.69^{\mathrm{c}}$ & 1.71 & \\
\hline & $2600 \mathrm{Kcal} / \mathrm{kg}$ & $1.25^{\mathrm{f}}$ & $1.40^{\mathrm{e}}$ & $2.10^{\mathrm{a}}$ & 1.58 & 0.08 \\
\hline & Mean & 1.39 & 1.65 & 1.89 & & \\
\hline \multirow[t]{3}{*}{ Empty stomach } & $3000 \mathrm{Kcal} / \mathrm{kg}$ & $0.91^{\mathrm{bc}}$ & $1.19^{\mathrm{a}}$ & $1.00^{\mathrm{abc}}$ & 1.03 & \\
\hline & $2600 \mathrm{Kcal} / \mathrm{kg}$ & $0.84^{\mathrm{c}}$ & $1.21^{\mathrm{a}}$ & $1.13^{\mathrm{a}}$ & 1.06 & 0.04 \\
\hline & Mean & 0.87 & 1.20 & 1.06 & & \\
\hline
\end{tabular}

a,b,c Mean values within rows with different superscript letters are significantly different $(\mathrm{P}<0.05)$, SEM: Standard error of mean for energy and protein interaction. T1 $=3000 \mathrm{Kcal} / \mathrm{kg} \mathrm{x} 18 \% \mathrm{CP}, \mathrm{T} 2=3000 \mathrm{Kcal} / \mathrm{kg} \mathrm{x} 16 \% \mathrm{CP}$, $\mathrm{T} 3=3000 \mathrm{Kcal} / \mathrm{kg} \times 14 \% \mathrm{CP}, \mathrm{T} 4=2600 \mathrm{Kcal} / \mathrm{kg} \mathrm{x} 18 \% \mathrm{CP}, \mathrm{T} 5=2600 \mathrm{Kcal} / \mathrm{kg} \times 16 \% \mathrm{CP}$ and T5=2600 Kcal $/ \mathrm{kg} \mathrm{x}$ $14 \% \mathrm{CP}$ 


\section{Amaefule, Onunkwo, Ilouno, Iwuji, Ogbuewu and Etuk}

Interaction effect of low energy and low crude protein diets supplemented with multi-enzyme on the live and relative organs weight of male growing pigs is presented in Table 4. The heart, lungs, empty caecum, full and empty stomach of male growing pigs fed $2600 \mathrm{Kcal} \mathrm{ME} \mathrm{x} 14 \% \mathrm{CP}$ diet had significantly $(\mathrm{P}<0.05)$ higher mean values when compared with those fed the control diet (3000 kcal x 18\% CP) and other lower $\mathrm{ME}$ and $\mathrm{CP}$ diets. Relative organ weights of male growing pigs fed low energy and low protein level diet (T4: $2600 \mathrm{kcal}$ x $18 \% \mathrm{CP}$ ) supplemented with multi-enzyme compared favorably with the heart, lungs, liver, kidney, empty caecum, full small intestine and empty stomach of those fed with T1 statistically. Increased live weight and decreased relative internal organs weight of male grower pigs fed low energy and low crude protein diet, supplemented with multi-enzyme (T4) could be attributed to an increased nutrient intake by the growing pigs as a result of multi-enzyme supplementation, leading to higher enzymatic activities (exogenous enzymes) which could have increased the digestive functions of these organs leading to a decrease in organ weight.

It could also be attributed to increased activities/secretion of the organs to digestive processes which led to improved performance (live weight) when compared with those fed with control diet (T1). This corroborates earlier report by Zhu et al. (2014), that enzyme supplementation in low protein diets increased the pancreatic and pepsin activities of broiler bird's leading to an increased nutrient digestibility and absorption capacity of the birds as well decreased the organ weights. Higher significant $(\mathrm{P}<0.05)$ values for heart, lungs, empty caecum, full and empty stomach recorded in male growing pigs fed $14 \% \mathrm{CP}$ diet (T3 and T6) with their corresponding metabolizable energy levels (3000 and $2600 \mathrm{kcal} / \mathrm{kg}$ ) supplemented with multi- enzyme as shown in Table 4. This observation could be as a result of higher fibre $(12.69 \%)$ content of the diets and lower protein content; this could prove that, the activities of multi-enzyme could be related to nutrient density of the diet, as there is a level of nutrient, multi-enzyme activities could not be effective especially when the dietary fibre content is too high. This is in line with the findings of Wenk (2001) who reported a significantly heavier stomach and caecum in growing-finishing pigs fed high dietary fibre.

The findings of this study disagree with that of Tengan et al. (2012) and Nsoh (2013), the authors observed a similar value pattern of internal organs for growing pigs that were fed with varying levels of African Locust Bean and soybean milk residue. The difference in their studies and the present study could be the influence of multienzyme activities, difference in nutrient levels of the diets, level of dietary fibre content and age of the growing pigs. Adesehinwa et al. (2019) reported similarities in the internal organs of finishing pigs fed diets containing rice mill by-products with or without Allzyme ${ }^{\circledR}$ supplementation which is not in corroboration with the findings of this study, the reason could be attributed to difference in enzyme composition and nutrient density of the experimental diets. According to NRC (2012), the nutrient requirement of growing pigs is reported to be $3400-3300$ $\mathrm{kcal} / \mathrm{kg}$ with a corresponding crude protein of $24-19.3 \%$ for $7-50 \mathrm{~kg}$ body weight for optimum performance, the result of this study has shown that improved performance was achieved when nutrient density of growing pig is reduced to $2600 \mathrm{Kcal} / \mathrm{kg}$ with $18 \%$ CP when compared with NRC (2012) recommended levels.

\section{Conclusion and recommendation}

The results from this study indicate that feeding growing pigs with low energy $(2600$ $105 \mathrm{Kcal} / \mathrm{kg}$ ) and low crude protein level (18\%) 
diets supplemented with multi-enzyme significantly improved live weight (growth performance)/ Keeping growing pigs on low crude protein diets (14\%) supplemented with multi-enzyme, irrespective of energy levels, did not improve live weight but increased relative organ weight of growing (male) pigs. Findings of this study showed that nutrient requirement for growing pigs can be reduced to $2600 \mathrm{Kcal} / \mathrm{kg}$ with a crude protein level of $18 \%$.

\section{References}

Adesehinwa, A. O. K., Obi, O. O., Makanjuola, B. and Durotoye, E. S. 2009. Use of sun-dried on-farm generated poultry litter as a feed resource by pigs in poultry-pig farm enterprise: implications on chemical composition of feed and blood chemistry. Institute of Agricultural Research and Training, Obafemi Awolowo University, Moor Plantation, Ibadan, Nigeria. International Symposium on Sustainable Improvement of Animal Production and Health, organized by Food and Agricultural Organization /International Atomic Energy Agency. Pg. 174-146

Ajayi, H. I. 2014. Ileal crude protein digestibility of feather meal supplemented with protease in broiler chickens. Ph,D. Thesis, University of Ibadan, Ibadan. Nigeria. 150pp.

Ajayi, H. I. and Imouokhome, J. I. 2015. Blood parameters and performance of broiler chickens fed diets containing feather meal at three crude protein levels, with or without protease supplementation Nigerian Journal of Agriculture, Food and Environment, 11(2): $146-149$.

Amaefule K. U. and Onyejekwe, E. I.
2015. Agro Industrial by-products for growing pigs; responses to low protein and low energy diets in the humid tropics, M.Sc. thesis Department of Animal Science. Michael Okpara University of Agriculture, Umudike, Abia State, Nigeria

Amaefule, K. U., Abasiekong, S. F., Ibe, S. N. and Onwudike, O. C. 2009. Digestibility and Nutrient Utilization of Some AgroIndustrial By-Products Fed to Growing Pigs in the Humid Tropics, Pakistan Journal of Nutrition 8 (4): 355-360.

Amaefule, R. A, 2016. Physiological responses of broiler birds to low energy and low crude protein diets supplemented with multienzyme in the humid tropical environment. M.Sc. thesis Department of Animal science. Michael Okpara University of Agriculture, Umudike, Abia State, Nigeria

Amaefule, R. A., Daniel- Igwe G., Amaefule, K. U. and Oguike, M. A. 2019. Relative organ weights of four-week old broilers fed low energy and low protein diets supplemented with multi-enzyme in the humid tropics Journal of Veterinary and Applied Science, Faculty of Veterinary Medicine, University of Nigeria Nsukka, 9(2) $14-20$

Dairo, F. A. S., Adeseinwa, A. O. K., Oluwasola, T. A. and Oluyemi, J. A. 2010. High and Iow dietary energy and protein levels for broiler chickens. African Journal of Agricultural Research, 5: 2030 2038

Dalolio, F. S., Moreira, J., Vaz, D. P., Albino, L. F. T., Valadares, L. R., Pires, A.V. and Pinheiro,S.R.F. 2016. Exogenous enzymes in diets 
for broilers. Revista Brasileira de Saude e Producao Animal., 17: 149-161.

Food and Agricultural Organization 2001. Bulletin of Statistics. Vol. 2, No. 1. Food and Agricultural Organization of the United Nations

Githigia, S. M., Okuthe, S. and Diop, B. 2012. Pig Sector Kenya. FAO Animal Production and $\mathrm{He}$ e $1 \mathrm{th}$ Livestock Country Reviews. No. 3. FAO, Rome. Available online: http://www.fao.org/3/ai2566e.pdf.

Lekule, P. F. and Kyvsgaard, N. C. 2003. Improving pig husbandry in tropical resource-poor communities and its potential to reduce risk of procine cysticercosis. Acta Trop. 87: 111117.

National Research Council. 2012. Nutrient requirements of swine. National Academic press, Washington, DC.

Nsoh Abora. 2013 growth performance, blood profile and carcass characteristics of growing pigs fed diets containing varying levels of soybean milk residue (sbmr), Master thesis submitted to the department of animal science, kwamenkrumah university of Science and Technology.

Serem, J. K., Wahome, R. G., Gakuya, D. W., Kiama, S. G., Gitao, G. C. andOnyango, D. W. 2017. Growth performance, feed conversion efficiency and blood characteristics of growing pigs fed on different levels of Moringa oleifera leaf meal. Journal of Veterinary Medicine and Animal Health, 9:327-333.

SPSS. Version 25. Statistical package for Social Science

Steel, R. G. D., Torrie, J. H., and Dickey, J. D. 1997. Principles and
Procedures of statistics: A Biometrical Approach (3 $3^{\text {rd }}$ Ed.). McGraw Hill Book Co., New York, NY

Tengan, K. D., Okai, D. B., Boateng, M. and Karbo, N. 2012. Nutritional evaluation of African Locust Bean Pulp (ALBP) -fruit fraction nutrient profile and effects of the pulp on the growth performance, blood constituents and carcass characteristics of growing pigs. Ghanaian Journal of Animal Science, 6(1): 62 - 68.

Tewe, O. O. and Egbunike, G. N. 1988. Utilization of cassava in nonruminant livestock feeds. In: Proc. IITA/IICA/Univ. of lbadan Workshop on the Potential Utilization of cassava as Livestock Feed in Africa, IITA, lbadan, November 14-18, 1988. pp. 28-38.

Unigwe, C. R., Raji, A. M., Ajayi, J. O., Popoola, A. M., Balogun, F. A. and Adekunle, F. O. $\quad 20017$. Carcass, Organ Weights and Histomorphology of Internal Organs of Sows Fed Fermented and Enzyme Supplemented Cassava Peels Meal (CPM) Based diets. Journal of Plant and Animal Sciences 2(1):26-36.

Wenk, C. 2001. The role of dietary fibre in the digestive physiology of the pig. Animal Feed Science and Technology 90: 21-33

Zhu, H. L., Hu, L. L., Hou, Y. Q., Zhang, J. and Ding, B. Y. 2014. The effects of enzyme supplementation on performance and digestive parameters of broilers fed cornsoybean diets. Poultry Science Journal.93: 1704-1712.

Received: $21^{1 s t}$ June, 2020 Accepted: $19^{\text {th }}$ December, 2020 